\title{
食品加工プロセスに打ける赤外線利用技術の開発
}

\author{
橋 本 篤 \\ 三重大学大学院生物資源学研究科資源循環学専攻
}

\section{Development of Infrared Radiative and Spectroscopic Applications to Food Processing}

\author{
Atsushi HASHIMOTO \\ Division of Sustainable Resource Sciences, Graduate School of Bioresources, Mie University \\ 1577 Kurimamachiya-cho, Tsu. Mie 514-8507, Japan
}

\begin{abstract}
Integrated investigation on application of infrared rays to food processing was dissertated from the view points of infrared radiation and spectroscopy. Drying and pasteurization of the food models were dealt in the most effective application of infrared radiation. The infrared drying characteristics of the food models were studied by focusing on the factors influencing their characteristics, and the importance of the diffusive infrared spectroscopic characteristics was emphasized for the quantitative evaluation of the effects of infrared drying. Moreover, infrared pasteurization of bacteria was more effective than the conventional thermal heating methods, and it was suggested that the infrared pasteurization effect was due to the absorption of infrared radiation energy by the sample in a very thin domain near the surface and to the bulk temperature. Then the infrared spectroscopy was studied for the qualitative and quantitative analysis of foods. In addition, the developed infrared spectroscopic methods were applied to get a good grasp of the sugar metabolic kinetics of suspension cells, the monitoring of the enzyme reaction associating with ionic dissociative metabolites, and the food tasting. Consequently, these studies represented an important step in the developments of the effective thermal operations and the on-line monitoring for food processing.
\end{abstract}

Keywords: infrared radiation, infrared spectroscopy, drying, pasteurization, sugar, plant cell, metabolic kinetics, enzyme reaction, tasting

1.は じめに

食品加工プロセスにおける赤外線の利用は, 熱エネ ルギ源としての利用と, 成分センシングに代表される 分光分析ッールとしての利用に大別される. 前者の代 表的な熱的操作としては, 乾燥や殺菌があげられる. 赤外線照射による加熱は，物理的な側面としては食品 の水分活性を低下させるための乾燥があげられ, 微生 物学的側面としては加工食品の初発菌数を低減させる ための殺菌があげられる。また, 赤外線乾燥は, さま ざまな分野で広く用いられており，食品分野でもその 伝熱効率の良さと仕上がり製品の風味などが優れてい るとの理由から多用されている. 一方, 赤外分光分析は,

(受付 2006 年 5 月 1 日, 受理 2006 年 5 月 25 日)

于 514-8507 三重県津市栗真町屋町 1577

† Fax: 059-231-9591, E-mail: hasimoto@bio.mie-u.ac.jp
各種官能基の基本振動情報に関する理論的基礎が存在 し, 解析も官能基の帰属波数帯だけを用いる単回帰で 十分なことが多いという特徵を有している。しかしな がら, 食品分野では食品中の高水分が障害となって応 用研究には限界があった.この問題点は近年普及して きたATR (Attenuated Total Reflection) 法 [1,2]によ り克服されつつある. また，赤外線などを用いた分光 計測 (電磁波計測) の最大の特徴は, 様々なバンドの 光を用いた一斉同時計測による情報量の多さと, 計測 に要する時間の短さにある. クロマトグラフィなどに よる計測では, カラムの選択などにより最終的に得ら れる情報が限定されるが, 分光計測では原スペクトル がもつ一次情報には基本的に情報の欠落がなく, 新た な解析法が見つかった時点で原スペクトルを用いた新 たな検討が可能になるという大きな利点も持ち合わせ ている.

本稿では, 赤外線の特徵を生かした食品加工プロセ 
スにおける熱的操作，モニタリング，制御技術の開発 を目的とし，工学的観点から行ってきた基礎的な研究 について概説する．主な課題は，赤外線加熱 [3-6]・乾 燥・殺菌，発酵過程・イオン解離性物質が関与する酵 素反応過程の赤外分光モニタリング，嗜好食品の味覚 関連情報の抽出である.

ところで，赤外線は大変広い分野において利用され ているが，それぞれの利用分野において異なる呼び名 の組み合わせを用いており，われわれは利用目的にお いて赤外線の分類が異なることを理解しておかなくて はならない. Fig. 1 に各利用分野における赤外線の分類 を示す．分光学の分野においては，分子の基準振動に 基づく波長帯を中赤外線とし，この波長帯よりも短波 長側を近赤外線，長波長側を遠赤外線とする。一般的 に中赤外線は波数を単位とし，4000 400 $\mathrm{cm}^{-1}$ と定義 され，波長では $2.5 〜 25 \mu \mathrm{m}$ に対応する．また，遠赤 外線は $400 \sim 10 \mathrm{~cm}^{-1}$ となり，波長では $25 \sim 1000 \mu \mathrm{m}$ の範囲である。中赤外域に現れる官能基の基準振動の 倍音・結合音が得られる近赤外線では，波長が使われ ることが多いが，波数も用いられる。一方，熱利用に おいては，3 $3 \mu \mathrm{m}$ よりも短波長域を近赤外線，逆に $3 \mu$ $\mathrm{m}$ よりも長波長域を遠赤外線とよんでいる [7].このよ うに，熱利用の分野に打いては，波長を単位として用 いるのが一般的である.

\section{2. 赤外線を利用した熱的操作}

赤外線による食品加熱が関与している現象は多岐に わたっているが，各々の現象は食品の赤外線による放 射伝熱機構の特色に起因するものと考えることができ る. 食品の保蔵性向上に関与する赤外線の放射加熱に よる現象は, 物理的な側面としての乾燥と, 微生物学 的な側面としての殺菌とに分けて考えることができる.

\section{1 湿潤多孔質食品モデルの赤外線乾燥特性}

被乾燥物による赤外線エネルギの吸収を水による吸 収と固体成分による吸収とに分けて考え $[5,6,8,9]$ ，蒸 留水を含浸させたメンブランフィルタ（試料 1 , 試料 2 , 試料 3 の平均空孔径は，それぞれ $3.94 ， 2.10 ， 0.74 \mu \mathrm{m}$ ) を 16 枚重ねた湿潤多孔質食品モデルの赤外線乾燥特性 の把握を試みた。Fig. 2 は，遠赤外線乾燥特性に及ぼす 平均空孔径の影響を検討した結果である [10-12]，恒率 乾燥速度に関しては，平均空孔径による顕著な差異は 認められないが，恒率乾燥期間後の乾燥速度の低下に 顕著な差異が認められた。最も平均空孔径が大きい試 料 1 の乾燥速度は, 恒率乾燥期間後, 最も高含水率で 乾燥速度が低下しはじめ, 試料 2 の乾燥速度は, 恒率 乾燥期間後, 最も低含水率で乾燥速度が低下しはじめ た. また，メンブランフィルタの拡散反射スペクトル

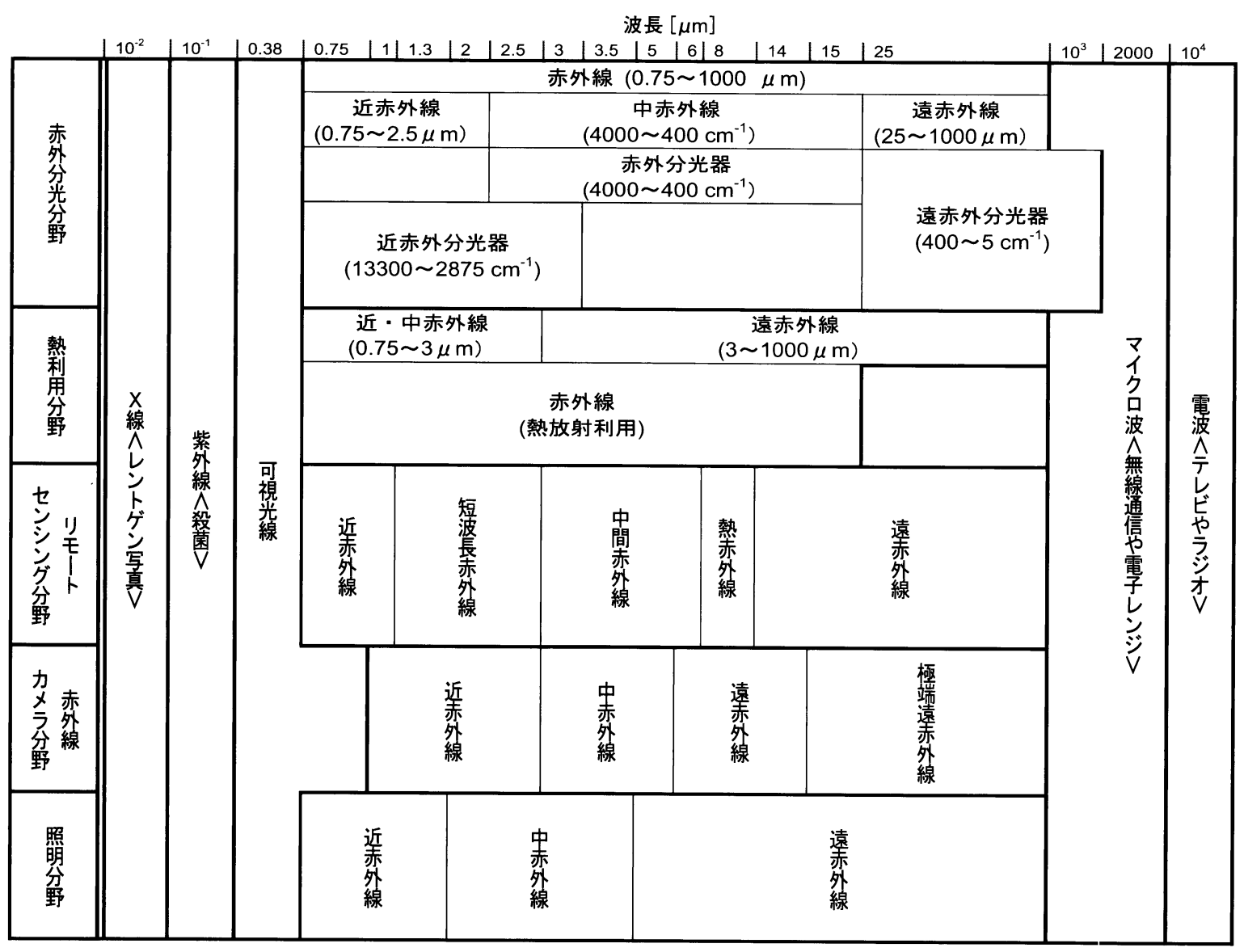

Fig. 1 Denomination of infrared ray in each application field. 


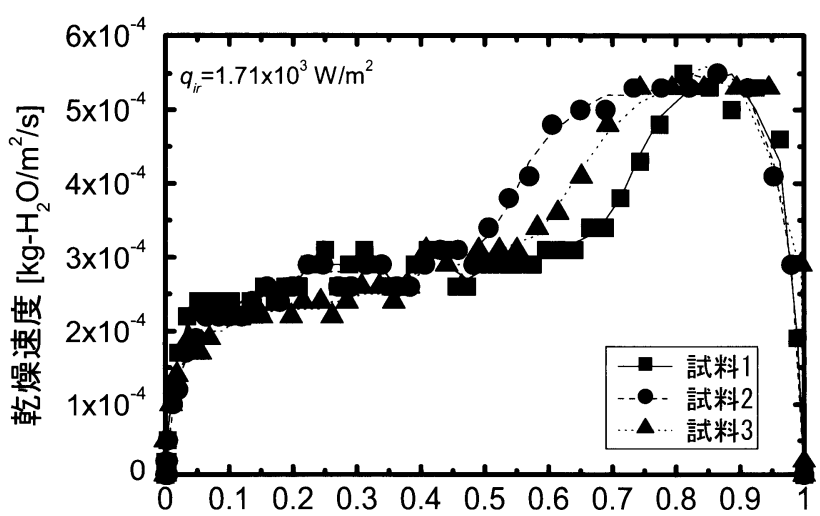

空隙体積基準含水率 $\left[\mathrm{m}^{3}-\mathrm{H}_{2} \mathrm{O} / \mathrm{m}^{3}\right.$-void]

Fig. 2 Effect of mean porous diameter of membrane filter on drying characteristics $\left(q_{\mathrm{ir}}=1.71 \times 10^{3} \mathrm{~W} \cdot \mathrm{m}^{-2}\right)$.

情報を用いて恒率乾燥期間に打ける乾燥試料による赤 外線エネルギの吸収量を推算したところ, 乾燥実験か ら求めた值と高い相関が認められた [10].さらに，湿 潤多孔質野菜の水分収着特性の解析 [13，14] と湿潤多 孔質食品モデルの通風乾燥特性のシミュレーションを 行い [12]，赤外線乾燥で非常に重要となる光学特性が FT-IR と拡散分光法の組み合わせで得られることを示 した $[10,11]$.つまり，これらの結果は，被乾燥物の赤 外線吸収特性に及ぼす乾燥過程における被乾燥物の水 分変化抢よび幾何学的構造変化の影響が，赤外線乾燥 機構の解明に重要であることを示唆している。

\section{2 赤外線照射による細菌の殺菌効果}

細菌縣濁液のバルク温度に着目し，遠赤外線照射に よる殺菌効果と伝導加熱による殺菌効果を比較した [15]. 遠赤外線照射もしくは伝導加熱された細菌懸濁 液のバルク温度の経時変化の差異を無視できる条件下 に打いて，遠赤外線照射もしくは伝導加熱した場合の 大腸菌の殺菌結果を Fig. 3 に示す [15]. ここで， $N_{1}$ は 細菌懸濁液中の生菌数濃度， $N_{10}$ はその初期值であり, $N_{1} / N_{10}$ は生残率を意味する. Fig. 3 に示すように，加 熱時間が同じであるならば遠赤外線照射した場合のほ うが伝導加熱した場合よりも生残率が小さくなった。 黄色ブドゥ球菌に関しても，同様の実駼結果が得られ た。つまり，遠赤外線照射による殺菌のほうが伝導加 熱による殺菌よりも効果的といえる.

また，固体表面および内部に存在する細菌に関して， 遠赤外線照射による殺菌効果と伝導加熱による殺菌効 果を比較した [16]。 その際，伝導加熱された寒天平板 内の各点の温度の経時変化と遠赤外線照射された寒天 平板内の各点の温度の経時変化とを実験的に揃えるこ とはきわめて困難であるので，供試細菌の寒天平板内 における熱死滅定数を用いて生残率を推算することに より，遠赤外線照射による殺菌効果と伝導加熱による
殺菌効果とを比較した．Fig. 4 にその結果を示す [16]. ここで， $N$ は寒天平板内の生菌数， $N_{0}$ はその初期值で あり, $N / N_{0}$ は生残率を意味する。 また,パラメータ $d$ は, 寒天平板表面から供試細菌までの距離である。大腸菌 と黄色ブドウ球菌の両供試細菌とも, $d \geqq 1 \mathrm{~mm}$ の領域 においては，実験結果と計算結果とは良好に一致して いる。，一方，寒天平板表面 $(d=0 \mathrm{~mm})$ の供試細菌に 関する遠赤外線照射による殺菌結果は，計算結果より も小さくなった。したがって，遠赤外線照射された寒 天平板表面温度の経時変化と伝導加熱された寒天平板 表面温度の経時変化が同じであるならば，遠赤外線照

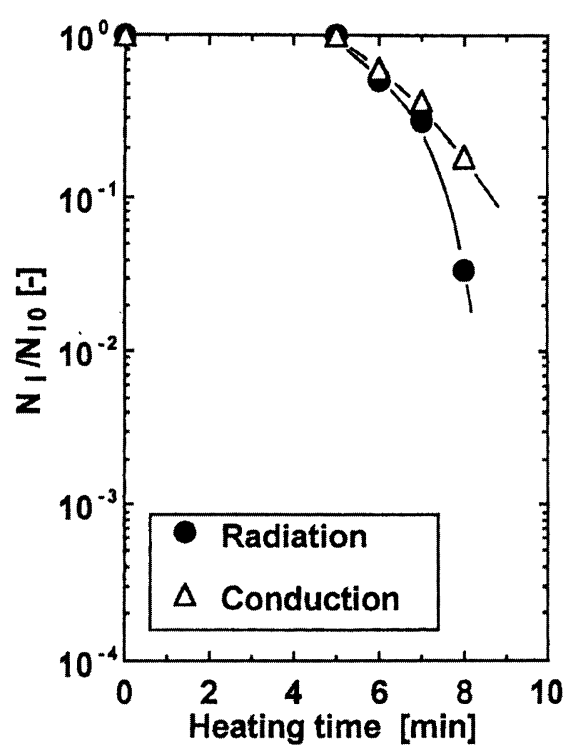

Fig. 3 Comparison of pasteurization effects on Escherichia coli suspension buffered saline heated by IR irradiation or conventional method. $N_{1} / N_{10}$ is viable ratio where $N_{1}$ is concentration of viable cells in bacterial suspension and subscript 0 means the initial state.

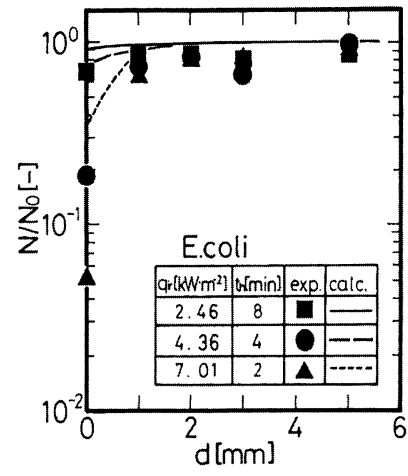

(a)

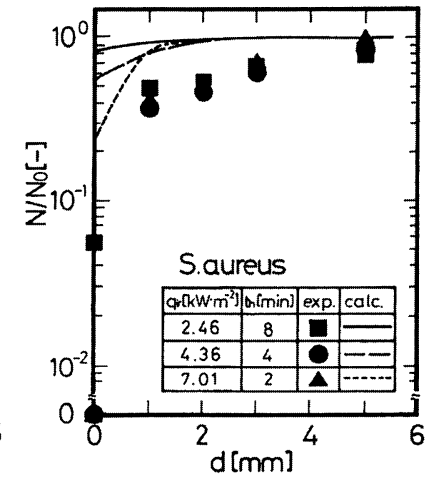

(b)
Fig. 4 Comparison of pasteurization effects on bacteria on or within agar heated by IR irradiation or conventional method. $N / N_{0}$ is viable ratio where $N$ is colony-forming unit per agar-plate [CFU $\cdot$ plate $^{-1}$ ] and subscript 0 means the initial state. (a) Escherichia coli, (b) Staphylococcus aureus 
射された寒天平板表面上の細菌の $N / N_{0}$ は, 伝導加熱

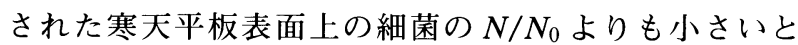
考えることができる. 一方， $d \geqq 1 \mathrm{~mm}$ の領域において は， $N / N_{0}$ の計算結果は，遠赤外線照射された供試細菌 の殺菌結果とほぼ一致した。このような殺菌効果の比 較より，寒天平板上の細菌の殺菌に関しては，遠赤外 線照射のほうが伝導加熱よりも効果的であることがわ かった.したがって，加工食品表面に付着した微生物 などに関しては，伝導加熱殺菌よりも遠赤外線照射殺 菌を行う方が効果的であると考えられた.

さらに，抗生剤を利用した細菌の損傷部位の新たな 検索方法を提示し，赤外線照射によって引き起こされ た損傷は，伝導加熱によって引き起こされた損傷と同 様な傾向を示した [17-21].このことは，赤外線照射さ れた細菌は，熱的効果によるストレスを受けた損傷と みなすことができるが，遠赤外線照射は伝導加熱より も殺菌に関して効果的な伝熱形態であることを示唆し た．また，赤外線照射による細菌牙胞の殺菌効果 [22] および対数増殖期の細菌の殺菌効果 [23] を明らかにす ることにより，赤外線照射殺菌の有効性は殺菌試料表 面近傍における照射エネルギの吸収機構に起因するこ とを伝熱工学的側面から明らかにした.

\section{3. 糖類の赤外分光スペクトル}

\section{1 単糖・二糖類のスペクトル}

解糖系の起点となり，デンプンなどの多糖類の最小 構成糖であるグルコースの水溶液中における ATR スペ クトルを Fig. 5 に示す [24]. これは，グルコース水溶 液スペクトルから，水溶液のモル分率を用いて重みゔ けを行った補償法により水のスペクトルを差し引いて 得られたものである. $3200 \mathrm{~cm}^{-1}$ 付近に $\mathrm{OH}$ 伸縮, 2925 $\mathrm{cm}^{-1}$ 付近に $\mathrm{CH}$ 伸縮, $1363 \mathrm{~cm}^{-1}$ 付近に $\mathrm{CH}$ 変角, 1079 $\mathrm{cm}^{-1}$ 付近にエーテル CO 伸縮および $1033 \mathrm{~cm}^{-1}$ 付近に

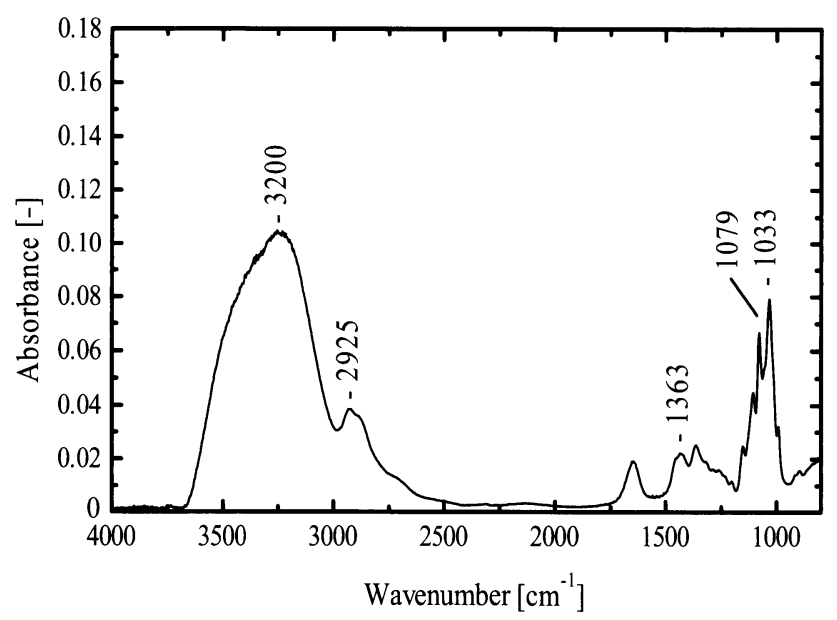

Fig. 5 IR spectrum of glucose in aqueous solution (1 M).
アルコール C-OH 伸縮のそれぞれの吸収が認められる. Fig. 6 に 4 種類の単糖（グルコース，フルクトース，ガ ラクトース，マンノース）の $1.0 \mathrm{M}$ 濃度水溶液の指紋 領域におけるスペクトルを示す [24]. $1200 \sim 950 \mathrm{~cm}^{-1}$ の領域のスペクトルは，エーテル CO 伸縮とアルコー ル $\mathrm{C}-\mathrm{OH}$ 伸縮の吸収帯が複雑に重なり合っているため, スペクトルパターンが糖によって大きく異なり，この 指紋領域のスペクトルは糖の定性分析に利用できるこ とがわかる.

次に，最も単純なオリゴ糖である二糖類の構造，お よび糖分子と水との相互作用に着目し，二糖類の赤外 分光特性について検討した $[25,26]$. D-グルコース 2 分子が結合したトレハロース（ $\alpha-1,1$ 結合), コウジビ

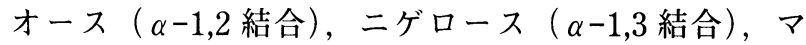
ルトース（ $\alpha-1,4$ 結合 $),$ およびイソマルトース（ $\alpha$ $-1,6$ 結合), ならびに D-グルコースと $\beta-\mathrm{D}-$ フルクトー スが $\alpha-1,2$ 結合したスクロースの指紋領域（1200〜 $\left.900 \mathrm{~cm}^{-1}\right)$ における ATR スペクトルを Fig. 7 に示す [25, 26]. この領域には, $1150 \mathrm{~cm}^{-1}$ 付近のピラノース環の

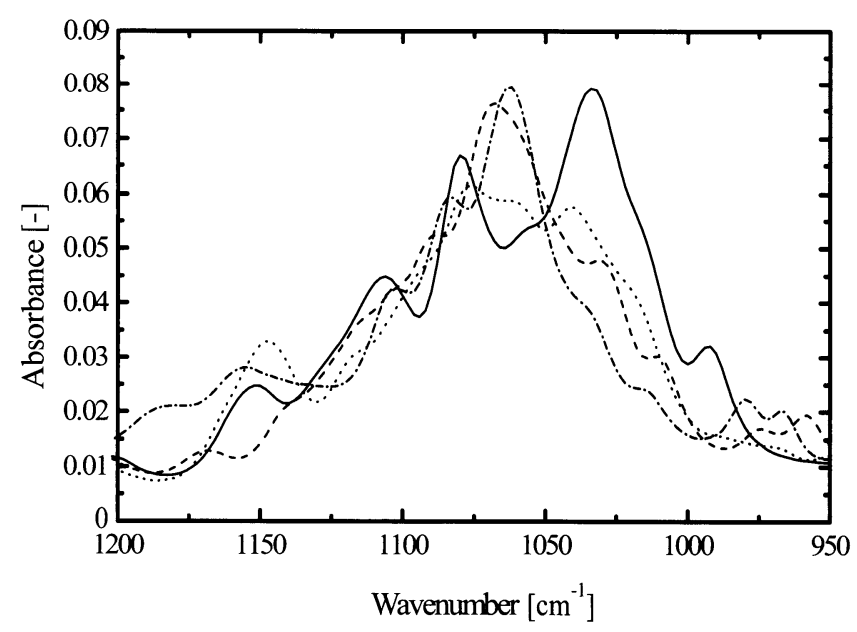

Fig. 6 IR spectra of monosaccharides in aqueous solutions (1 M). - glucose, ----- mannose, $\cdots \cdot$ galactose, $-\cdot-$ fructose

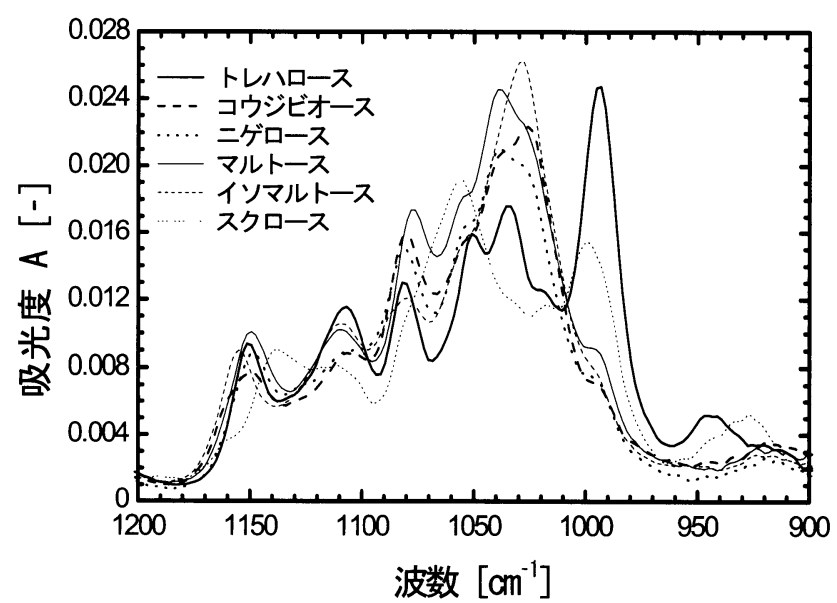

Fig. 7 IR spectra of disaccharides in aqueous solutions (30 mM). 
振動, $1100 \mathrm{~cm}^{-1}$ 付近の $\mathrm{C}-\mathrm{C}, \mathrm{C}-\mathrm{O}$, および $\mathrm{C}-\mathrm{OH}$ の 複合振動, $1060 \mathrm{~cm}^{-1}$ 付近の $\mathrm{C}-1-\mathrm{H}$ の変角振動, およ び $1030 \mathrm{~cm}^{-1}$ 付近の $\mathrm{C}-\mathrm{OH}$ の伸縮振動等, 様々な官能 基の振動の吸収が混在する. Fig. 7 より, 糖分子の構造 により若干の差異があるものの，D-グルコース 2 分子 が結合した二糖では, 各振動の吸収帯はほぼ同じ波数 に存在することが確認された。トレハロースは他の二 糖と比較して特異的なスペクトルパターンを有するこ とが示された

また，トレハロース，マルトース，扰びスクロー ススペクトルの代表的なピーク波数である $992 \mathrm{~cm}^{-1}$, $1035 \mathrm{~cm}^{-1}$ ，および $996 \mathrm{~cm}^{-1}$ における検量線を求めたと ころ，スクロースだけが， $0.5 \mathrm{M}$ 以上で非直線性を示し た [25].つまり，スクロースの $996 \mathrm{~cm}^{-1}$ は $\mathrm{C}-\mathrm{OH}$ の伸 縮振動に起因する吸収帯と考えられ，糖と水との相互 作用を受けていることが示された。ささらに，トレハロー ス，マルトース，およびスクローススペクトルの上記 3 ピーク波数について, 最も安定している飽和溶液濃度 近くのスペクトルを基準に波数シフトを求めた。 その 結果，トレハロースのみ，波数シフトが $3 \mathrm{~cm}^{-1}$ 以内に なり，水との相互作用が濃度によって大きく変化しな いことが示された [26]. 以上より，最も単純なオリゴ 糖である二糖類に関しても，その構造および糖分子と 水との相互作用が赤外分光特性に影響を及ぼすことが わかった。

\section{2 オリゴ糖のスペクトル}

近年，砂糖に代わる甘味料として，オリゴ糖などの 低甘味度甘味料の需要が年々増大している。オリゴ糖 はまたさまざまな生理活性機能も有しており，任意の 重合度のオリゴ糖精製が求められるようになり，オリ ゴ糖の精製過程における高精度の品質管理に関わるオ ンラインセンサの必要性も高まっている。そこで，グ

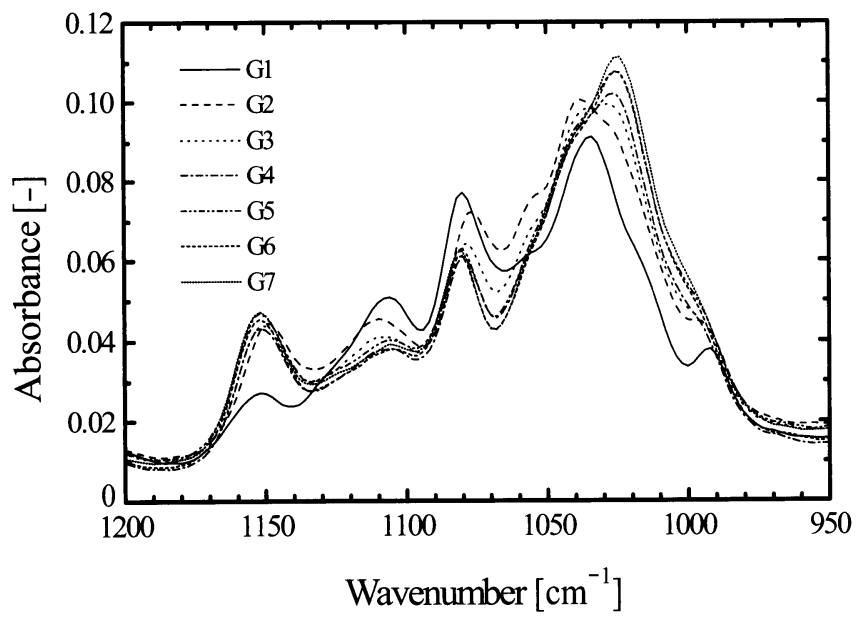

Fig. 8 IR spectra of maltooligosaccharides in aqueous solutions (0.2 g-sugar/4.0 g-solution).
ルコースからグルコース重合度が 7 の直鎖オリゴ糖ま で赤外分光スペクトル $(\mathrm{G} 1 \sim \mathrm{G} 7)$ を計測し，それぞ れのスペクトルの特徴を Fig. 8 に示した [27]. グルコー ス重合度が 1 から 4 までの G1，G2，G3，G4 の波形は 似ているものの，それぞれのスペクトルは明らかに異 なることが分かる。 また，重合度が 5 から 7 にかけて のオリゴ糖（G5，G6，G7）ではスペクトルパターンは 非常に近いものとなった。ささらに，これらのスペクト ルを波形分離し，重合度により基数が変化する官能基 （C-O-C）に起因する吸収に着目し，その官能基数と吸 光度との関係を考察することにより，重合度の推定を 試みた。その結果，相関係数が 0.999 の精度で重合度を 推定することができたが，重合度が大きくなるほどそ の推定が困難になることがわかった [27].

\section{3 イオン水溶液中の糖のスペクトル}

生体内に打ける塩類は細胞内浸透圧の調整等の機能 をもち，その塩類を構成する陽イオン種として $\mathrm{Na}^{+} ゃ$ $\mathrm{K}^{+}$が挙げられる。そして，単・二糖類に代表される糖 類とともに代謝に関連する重要な物質であり，それら の相互作用を考虑した赤外分光計測が望まれている. そこで, 塩類が塩水溶液および塩水溶液中の糖類の赤 外分光特性に及ぼす影響とその濃度依存性について検 討した. Fig. 9 に水のスペクトルおよび $\mathrm{KCl}$ 水溶液の 濃度変化スペクトルを示す [28]. $\mathrm{KCl}$ 濃度の変化に対 して，OH 伸縮および $\mathrm{OH}$ 変角のスペクトルパターンが 連続的に変化した．5種類のアルカリ金属塩化物につい て，その傾向は， $\mathrm{OH}$ 伸縮の吸収帯において顕著であっ た。さらに, $2.0 \mathrm{M}$ 水溶液中のグルコーススペクトルに 及ぼすアルカリ金属塩化物の濃度の影響について，糖 の指紋領域 $\left(1200 \sim 950 \mathrm{~cm}^{-1}\right)$ に着目し解析を行った. その際，グルコース水溶液およびグルコース $-\mathrm{KCl}$ 水溶 液スペクトルから，重みづけを行った水打よび $\mathrm{KCl}$ 水

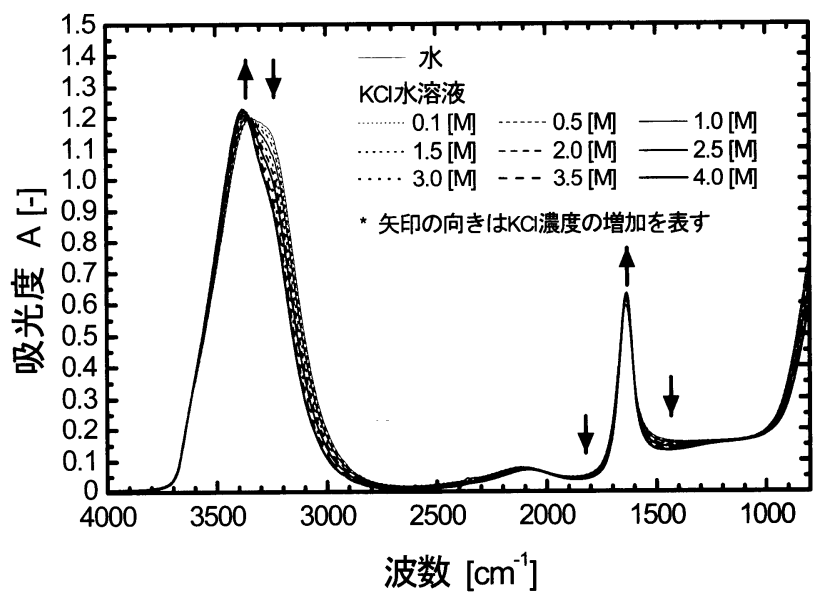

Fig. 9 IR spectra of $\mathrm{KCl}$ aqueous solutions. 
溶液のスペクトルをそれぞれ差し引くことにより, $\mathrm{KCl}$ 濃度（0〜3.5 M) の影響を受けた水溶液中のグルコー ススペクトルを抽出した。なお，重みは各溶液の体積 モル濃度より計算した。 そして, $\mathrm{KCl}$ 濃度 $0 \mathrm{M}$ のグル コーススペクトルを基準として，それぞれのスペクト ルとの差を求めた。この波数領域に打けるグルコース スペクトルには, $1150 \mathrm{~cm}^{-1}$ 付近のピラノース環の振動, $1079 \mathrm{~cm}^{-1}$ 付近の $\mathrm{C}-1-\mathrm{H}$ の変角振動, $1032 \mathrm{~cm}^{-1}$ 付近の $\mathrm{C}-\mathrm{OH}$ の伸縮振動, および $992 \mathrm{~cm}^{-1}$ 付近の $\mathrm{CH}_{2} \mathrm{OH}$ の 振動等, 様々な官能基の振動の吸収が混在する，その 結果，各官能基が $\mathrm{KCl}$ 濃度から受ける影響は，スペク トルにおける吸収波数よりも低波数側に認められ， $\mathrm{KCl}$ 濃度に対応して増加することがわかった [28].

\section{4. 食品・農産物の赤外分光解析}

\section{1 果汁モデルの定量分析}

Figs.6, 7 に示したように，指紋領域に各糖固有のス ペクトルを測定できるので, FT-IR/ATR 法を用いるこ とにより，各糖濃度を同時に定量できるものと考えら れる. そこで, 単糖類・二糖類の混合糖水溶液に対して, FT-IR/ATR 法を用いて糖の定性・定量分析を行った. モデル食品としてナシ果汁を想定した混合糖水溶液の 吸光度スペクトルと，スペクトルの加成性を想定して 計算により合成したスペクトルの指紋領域における吸 光度スペクトルを比較したところ, 2 つのスペクトルは, 定性的，定量的にもよく一致し，指紋領域での精度の 高い加成性が示された [29]. ナシ，モモ，ブドウ，リ ンゴ, ミカンの模擬果汁の吸光度スペクトルから通常 法で求めたグルコース，スクロース，フルクトースの 濃度と実際の濃度の関係では, 相関係数は 0.985 となり PLS 解析などには若干劣るものの良好な結果が得られ た [29].

また，収穫後も典型的な追熟現象を示すトマトを対 象とし，その追熟過程における内部品質変化を評価す るために，赤外分光法を用いて糖成分の計測を行った. その結果, トマト各部位間においてグルコース, フル クトース，スクロース含量に若干の差異はあるものの, 貯蔵前後では大きな差異は認められなかった [30]. 追 熟過程において呼吸代謝により糖が消費されているこ とを考慮すると，追熟にともなう軟化，つまり細胞壁 多糖類の分解により生成された糖を炭素源として呼吸 代謝が営まれていることが推測できた。 このように, FT-IR/ATR 法は, 簡易に糖含量を定量できることから, その定量結果を利用した代謝等に関する研究の発展に もきわめて有効な手段と考えられる.

\section{2. みかん果汁の赤外分光解析}

有機酸の多くは代謝を制御する重要な物質であると
ともに，食品においてはその味覚に大きな影響を及ぼ す成分である.また，理論的にはすべての酸について 赤外分光分析は可能である. そこで，ミカン果汁を例 にとり, 酸 (クエン酸) と糖類との同時定量の可能性 について研究した.

まず，クエン酸水溶液と水との差スペクトルを求め たところ，3600 $\mathrm{cm}^{-1}$ に OH 基の $\mathrm{OH}$ 伸縮，2400 $3050 \mathrm{~cm}^{-1}$ に $\mathrm{COOH}$ 基の幅広く強い $\mathrm{OH}$ 伸縮, 1722 $\mathrm{cm}^{-1}$ に $\mathrm{COOH}$ 基の $\mathrm{C}=\mathrm{O}$ 伸縮, そして $1224 \mathrm{~cm}^{-1} に$ $\mathrm{CH}_{2}$ 基の縦ゆれ振動に基づく吸収ピークが認められた [31]. また, 定量分析の前提となるクエン酸, スクロー ス，フルクトース，グルコースのスペクトルの加成性 について検討したところ, 計算上の果汁モデルスペク トルと果汁モデルの実スペクトルには良い一致が認め られた [31]. そこで，糖類による主たる吸収ピークが なく, クエン酸に特徵的なピークが認められる 1722 $\mathrm{cm}^{-1}$ に扣いてクエン酸の検量線を作成し, みかん果汁 スペクトルからクエン酸濃度を算出して, 酸度測定よ り得られたみかん果汁の酸度から求めたクエン酸濃度 と比較した(Fig. 10) [31].この図より, 計算值と実測 值が良く一致し, 中赤外分光法を用いたクエン酸の定 量は $1722 \mathrm{~cm}^{-1}$ 近傍で可能であることが判明した.

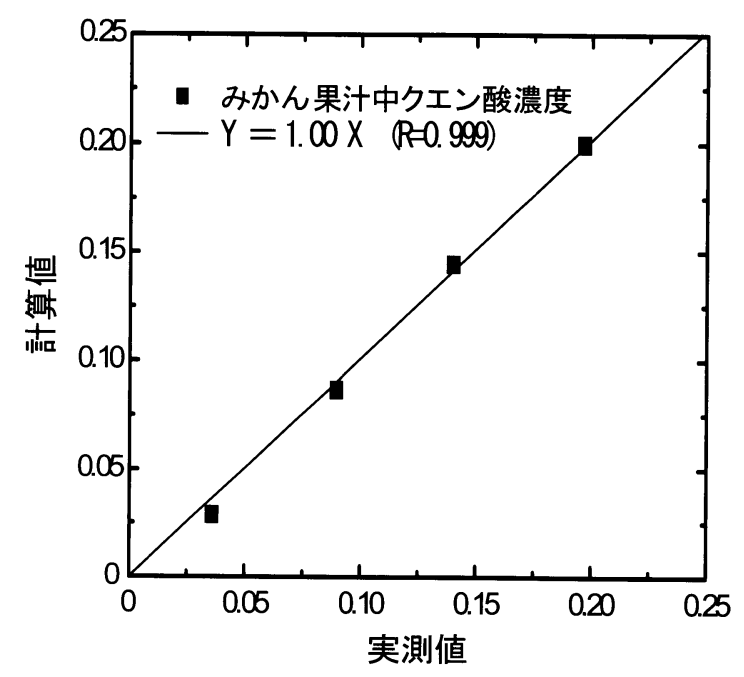

Fig. 10 Comparison of calculated content of citric acid in orange juice with actual one.

\section{5. 懸濁細胞の糖代謝計測}

発酵を利用した製品製造は, 食品分野に限らず様々 な分野で行われており，発酵停止のタイミング，もし くは発酵過程のモニタリングは重要な課題である，食 品分野に関連する主な研究としてアルコール発酵と乳 酸発酵である.アルコール発酵では，キー物質として グルコース，フルクトース，グリセロール，エタノー ルが用いられ，赤外分光スペクトルを用いたこれらの 
成分の連続計測が研究されている $[32,33]$.

\section{1 ヨーグルト発酵過程のモニタリング}

ヨーグルトスタータとして用いられる乳酸菌は，ラ クトースを炭素源として発酵して乳酸を生成し，乳酸 の解離した水素イオンがタンパク質の等電点まで $\mathrm{pH}$ を 低下させてタンパク質を凝固させる．通常の中和滴定 法による乳酸酸度測定は，測定者による誤差が大きく， また測定時間を有するためタイムリな発酵の制御は困 難である。そこで，ラクトーススペクトルの吸光度の 減少から乳酸酸度を求めることにより, 乳酸発酵過程 のモニタリングを目指し，とくにヨーグルトスタータ の接種量と培地濃度を変えて培養したときの結果につ いて説明する. Fig. 11 はヨーグルト発酵過程における ヨーグルト中のラクトーススペクトルであり [34], 発 酵中にラクトースが消費されてゆく挙動がわかる．ま た，培地濃度を $12 \%$ で固定し，スタータの接種濃度を $1 \% ， 3 \% ， 5 \%$ の条件下でョーグルト発酵させたときの吸 光度と滴定酸度との関係を検討したところ，ラクトー ススペクトルの $1075 \mathrm{~cm}^{-1}$ における吸光度と滴定酸度に 関する検量線は非常に高い直線性を示し，スタータの 接種濃度に依存しないことが示された [34]. 一方，ヨー グルト発酵の際に生じるタンパク質変性の様子を Fig. 12 に示した [34]. ヨーグルトが固まりはじめる前後（3 〜 4 h) でのタンパク質の変化がよくわかる.

\section{2 植物細胞の糖代謝解析}

懸濁細胞の生命活動は，外界に存在する培地情報だ けではなく，他の細胞の存在状態に関する情報を入手 し，培地から能動的に物質を取り込みつつ営まれる. このような細胞の活動の場である培地の成分濃度計測 では，培養の初期状態として存在する成分以外の成分 が細胞によって創り出されることが多い。このような 状況での培地内部の成分変化計測に関して，FR-IR/

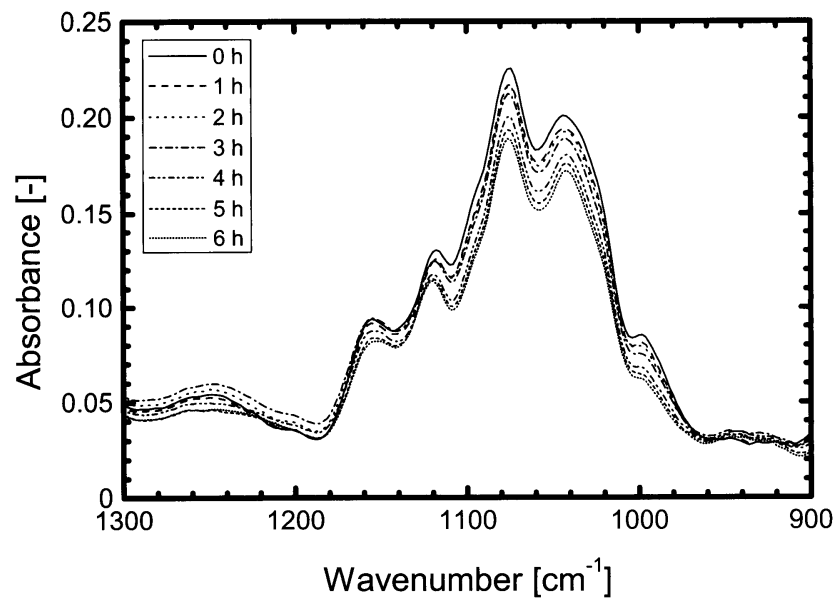

Fig. 11 Time behavior of IR spectra of lactose in yogurt fermentation medium.
ATR 法を適応した例 $[35,36]$ を以下に示す.

懸濁植物細胞としてイネ細胞，培地としてショ糖が 主成分の $\mathrm{R} 2 \mathrm{~S}$ 培地を用いた。この実験系では，イネ細 胞から分泌されるインベルターゼなどの酵素によって 培地中のスクロースがグルコースとフルクトースに分 解されることが知られている. Fig. 13 に培養過程での 培地のスペクトル変化を示すが [36]，8日後のスペク トルパターンはスクロースのパターンと異なり，グル コースとフルクトース混合物のスペクトルパターンに 酷似していることが確認された。また，12 日後には $1045 \mathrm{~cm}^{-1}$ 付近にエタノール生成に起因すると考えられ るシャープな吸収ピークが認められた。 そこで，この スペクトルがスクロース，グルコース，フルクトース， エタノールの 4 成分からなるとの仮定で計算した各糖 濃度，および従来法として HPLCを用いて求めた各糖 濃度の経時変化を Fig. 14 に示す [36]. 両者の経時変化 は定性的・定量的に類似しており，FT-IR/ATR 法が植 物細胞培養過程の糖代謝計測に有効な手段であること

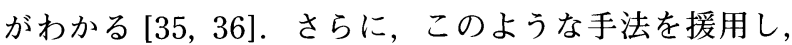

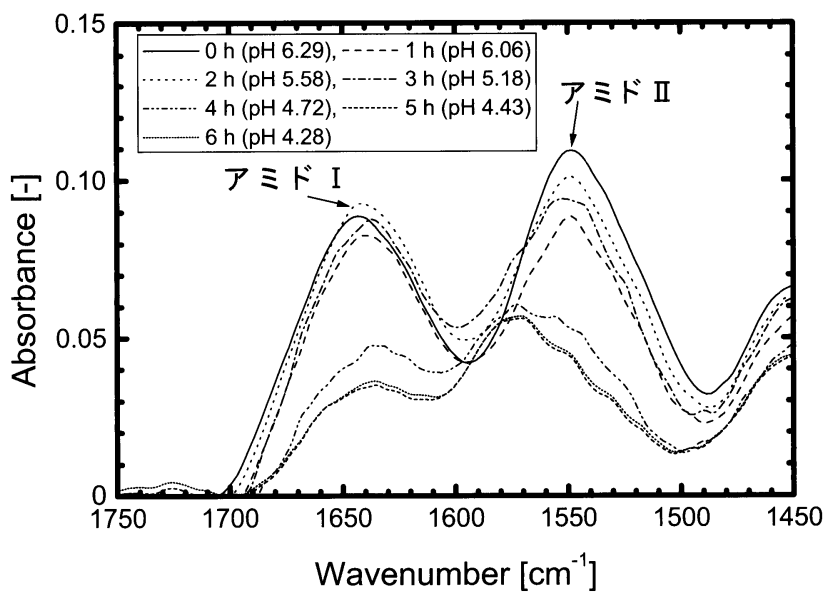

Fig. 12 Time behavior of IR spectra of protein in yogurt fermentation medium.

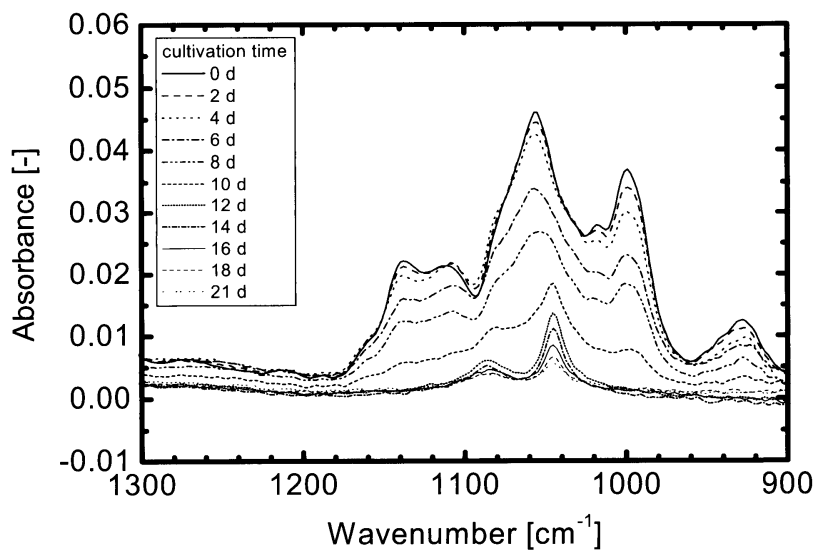

Fig. 13 Time behavior of IR spectra of culture medium component during sucrose cultivation of rice cells. 
懸濁植物細胞の動的糖代謝解析が可能であることが示 されている [37-39].

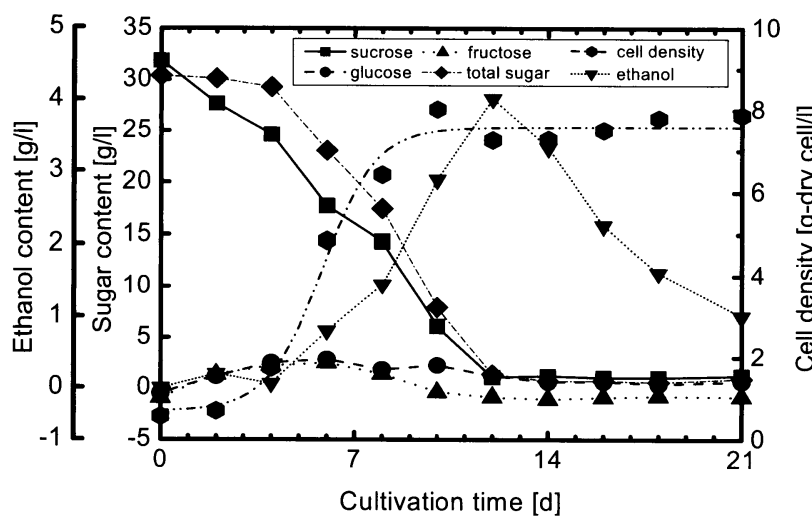

Fig. 14 Time courses of sugar content, ethanol content, and dry cell weight during sucrose cultivation of rice cells.

\section{6. イオン解離性物質が関与する酵素反応モニタリング}

代謝関連物質のなかには，解糖系やペントースリン 酸回路における糖リン酸, TCA 回路における有機酸, エネルギ代謝物質としてのアデノシンリン酸などイオ ン解離性物質が数多く存在している. イオン解離性物 質の赤外分光スペクトルは $\mathrm{pH}$ によって顕著に変化する

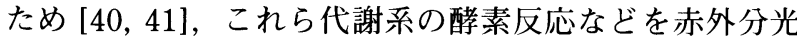
法によって測定する際には，その赤外分光スペクトル の $\mathrm{pH}$ 依存性に関する情報が重要である。ここではエネ ルギ代謝全般に関わるアデノシンリン酸，および解糖 系の初期の反応に関わるグルコース-6- リン酸 (G6P), フルクトース-6-リン酸（F6P） を対象とし $\mathrm{pH}$ 依存性 を考慮した赤外分光特性について説明する。

\section{1 イオン解離成分のスペクトル}

Fig. 15 は G6Pの赤外分光スペクトルに及ぼす $\mathrm{pH} の$ 影響である [40]. 吸光度スペクトルが $\mathrm{pH}$ の変化に対 して連続的に変化し，主要なピークが顕著に消長する 様子が示されている，そこで，解離によって生じた各

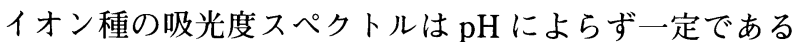
こと，各イオン種のスペクトルの加成性が成り立つこ とを仮定し，吸光度と各イオン種の濃度との関係に対 して重線形回帰を行うことにより各イオン種の吸光度 スペクトルを抽出した．Fig. 16 は ATP, ADP，AMP についてそれぞれ弱酸性域で支配的となるイオン種の スペクトルを示したものである [40]. リン酸基が多い 程スペクトルは複雑化していき吸光度も大きくなって いる. とくに $1050 \sim 1150 \mathrm{~cm}^{-1}$ 付近のピークの数はリ ン酸基の数に対応して増していくことがわかる。この ように，解離性物質の分光スペクトルの $\mathrm{pH}$ 依存性を解 離平衡の理論を用いて解析することにより，各イオン
種の赤外分光スペクトルを抽出することができ，そこ から代謝関連物質の赤外分光特性に関する詳細な情報 を得る可能性が示唆された。

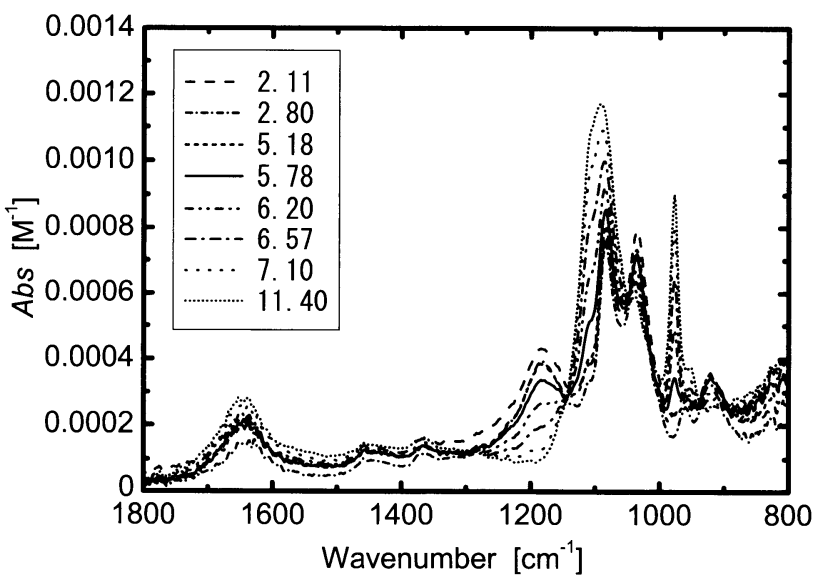

Fig. 15 pH dependency of molar absorbance spectra of G6P.

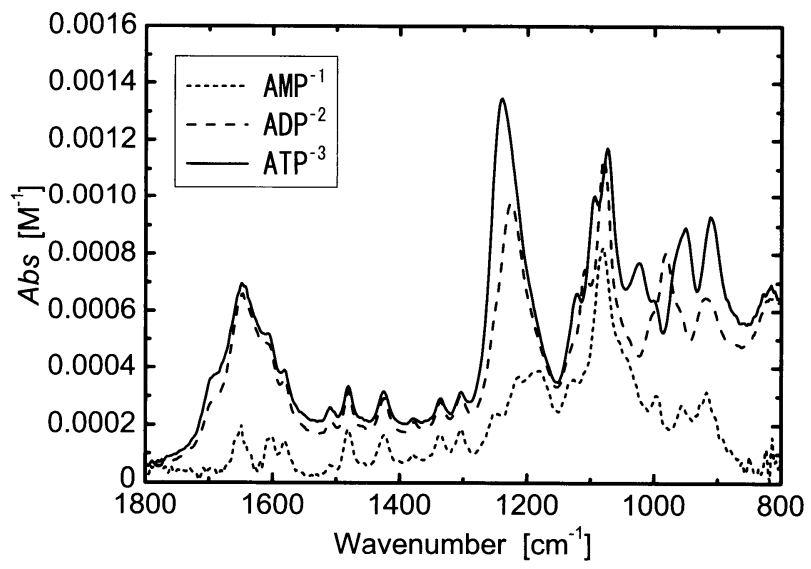

Fig. 16 Comparison of the spectra of $\mathrm{ATP}^{3-}, \mathrm{ADP}^{2-}$, and $\mathrm{AMP}^{-}$, whose abundances are the greatest in the $\mathrm{pH}$ rage from 4 to 6 .

\section{2 酵素反応過程の連続モニタリング}

様々なイオン解離性代謝物質が代謝反応に関与し, 極めて重要な役割を果たしている，そこで，6.1で述べ た手法により得られる各解離成分のスペクトルの加成 性に基づき，各解離成分の吸収波数における 2 次微分 值を用いて, G6P-F6P-Tris 溶液中の各解離成分濃度の 線形重回帰分析を試みた。そして, $\mathrm{pH}$ の緩衝成分であ る Tris の解離成分比から解離平衡を仮定して $\mathrm{pH}$ を推 定し，さらにその $\mathrm{pH}$ に基づいて G6P， F6P，Tris 濃度 を求めた $[42,43]$. その結果, $\mathrm{pH}$ と各成分濃度に関す る調製値と推定値の相関係数はすべて 0.995 以上であっ た (Fig. 17) [42].

さらに，リアルタイム赤外分光計測法を援用するこ とにより，イオン解離性の酵素反応過程の連続モニタ リングを試みた。その際，解糖系の入り口にあたる部 分の反応に着目し， G6P から F6Pへの異性化反応を対 

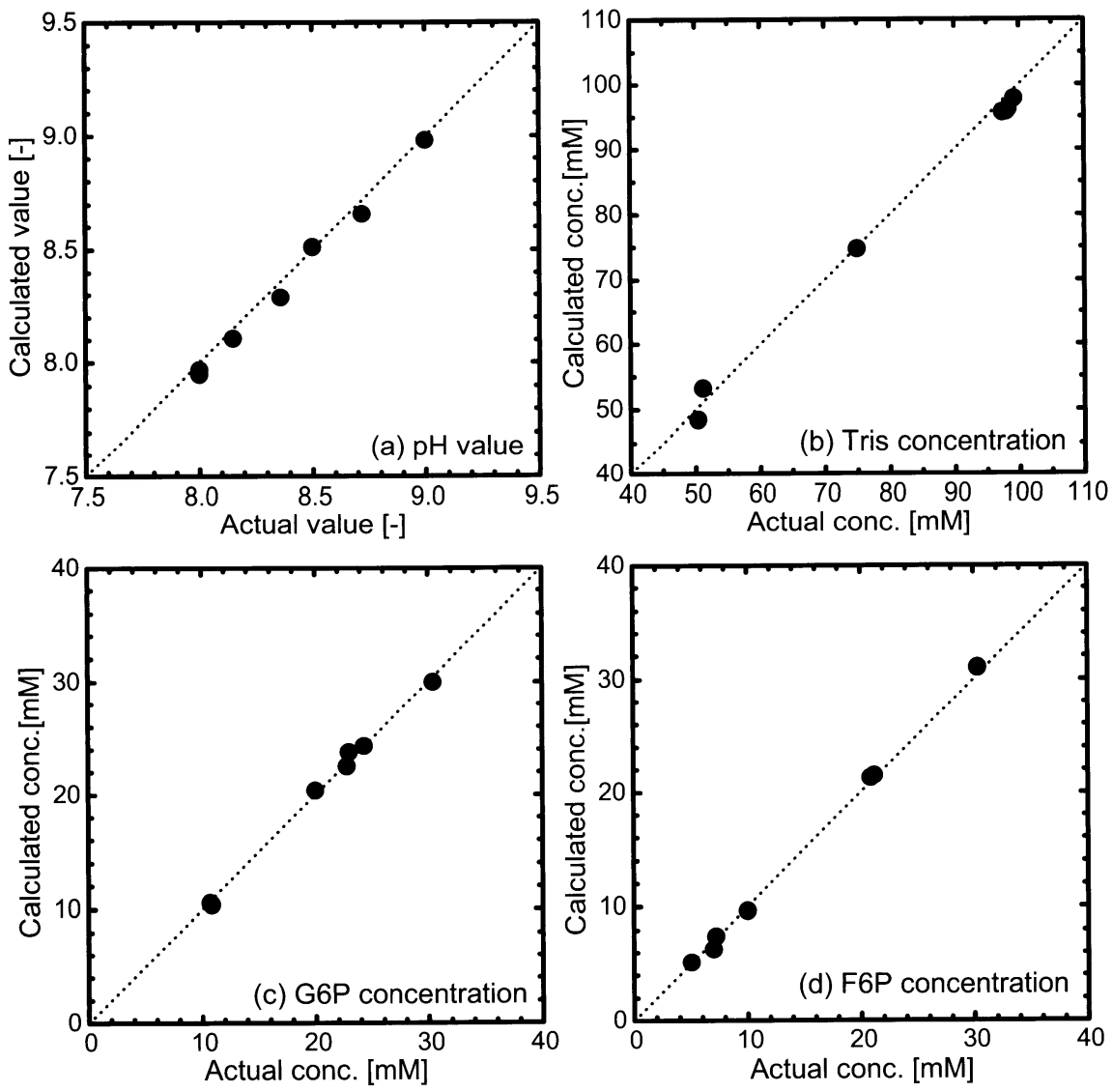

Fig. 17 Comparison of calculated value and actual value: (a) $\mathrm{pH}$ value, (b) Tris concentration, (c) G6P concentration, (d) F6P concentration.

象とした。また，酵素には好熱性細菌由来のグルコー ス-6-リン酸イソメラーゼを用い，溶媒には $100 \mathrm{mM}$ の Tris- $\mathrm{HCl}$ 緩衝液を使用した. 酵素反応連続モニタリ ングシステム [44] を用い，酵素反応の設定温度 $\left(40^{\circ} \mathrm{C}\right)$ でスペクトルを測定し，そのスペクトル情報に基づい て G6P-F6P-Tris 混合溶液の定量を試みた。その際, 解離定数 $\mathrm{pK}$ 值の温度依存性を考慮することで, 選択さ れた吸収波数ごとに混合溶液の吸光度二次微分と各イ オン解離成分の吸光度二次微分との関係に対して線形 重回帰を行い, $40^{\circ} \mathrm{C}$ における G6P-F6P-Tris 混合溶液 の $\mathrm{pH}$ と各成分濃度を求めた. Fig. 18 は, 酵素反応過 程に打ける各成分濃度と $\mathrm{pH}$ を求めた結果である [44]. 定量した G6P および F6P 濃度の経時変化は，理論計算 結果とほぼ一致した。また，赤外分光スペクトル情報 から推定した $\mathrm{pH}$ 值は反応中ほぼ一定であった.つまり, 赤外分光法を援用することにより，イオン解離性物質 が関与する酵素反応液中の成分変化拉よび $\mathrm{pH}$ 值のリア ルタイムモニタリングが可能となった。これらの結果 は，複数の解糖系酵素反応を連続・並列反応に進行さ せた場合の反応動力学パラメータの取得，およびそれ ら反応動力学パラメータの再構築の可能性を示唆した ものといえる.
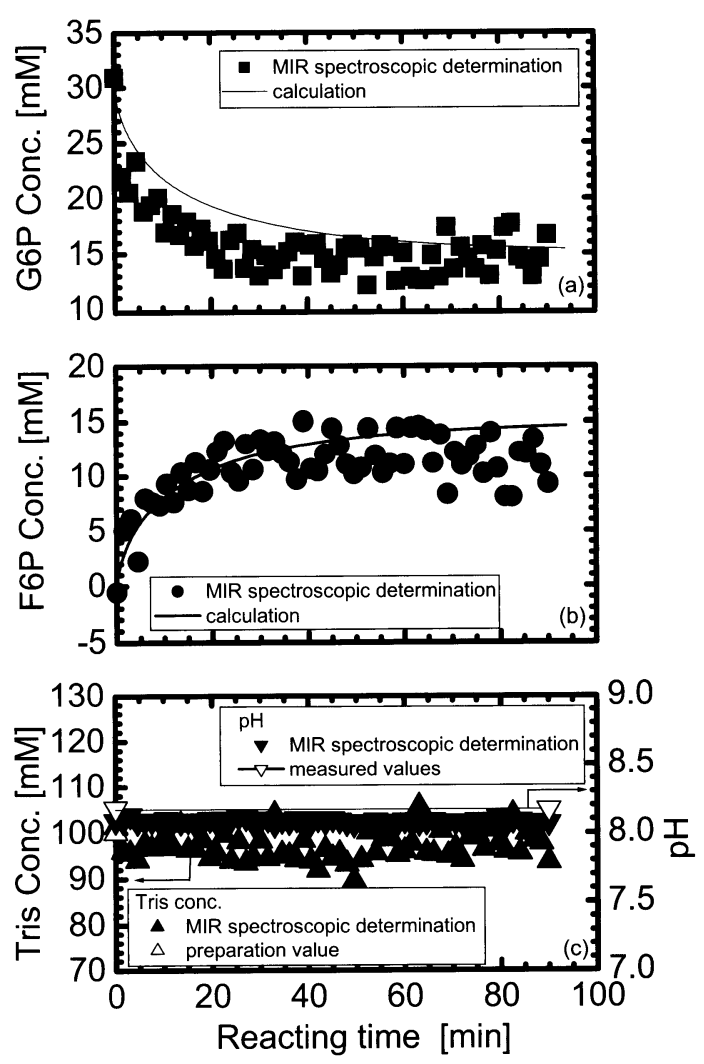

Fig. 18 Time courses of metabolite concentration and $\mathrm{pH}$ value during enzyme reaction: (a) G6P concentration, (b) F6P concentration, (c) Tris concentration and $\mathrm{pH}$ value. 


\section{7. 赤外分光法を援用した味覚関連情報の抽出}

味覚に影響を与える要因として食品中の化学成分が あり，化学成分を客観的に評価することが，安定した 食品の味覚評価, 生産, および供給につながる。そこで, 複数成分の同時計測, 定性, および定量の可能性を有し, 成分の相互作用を把握できる赤外分光法が注目されて いる.ここでは，代表的な嗜好飲料としてコーヒーに 着目し, 各主要成分の赤外分光特性を把握するととも に，ワインの銘柄の識別の可能性などに関して概説す る.

\section{1 コーヒーの赤外分光特性}

コーヒー（サントス）抽出液の二次微分スペクトル に及ぼす加水比の影響を検討したところ，特徵的なピー ク が $1385,1286,1242,1213,1190,1151,1122$ $\mathrm{cm}^{-1}$ 付近に確認できた [45]. そして，それぞれのピー クにおける二次微分值とコーヒー濃度の指標である Brix との間に高い相関が得られたので，これは抽出液 中の成分のピークであるものと考えられた。 また，加 水比を $25 \mathrm{~g} / 150 \mathrm{~g}$ とし，コーヒ一抽出液の二次微分ス ペクトルに及ぼす原産地の影響を検討した（Fig. 19） [45]. $1385 \mathrm{~cm}^{-1}$ でサントス，インドネシア(1), インド ネシア(2), 1369, 1286, $1242 \mathrm{~cm}^{-1}$ でインドネシア(1), インドネシア(2), 1292, 1190, $1151 \mathrm{~cm}^{-1}$ でインドネシ ア(2)の識別ができた。つまり，焙煎度，品種が異なる ものは識別でき，アラビカ種の中ではサントスの識別 が可能と考えられた。

一方, コーヒ一主要成分として, コーヒ一抽出液中 の含有量が多くかつ味覚に影響を与えるカフェイン, トリゴネリン，クロロゲン酸，クエン酸，キナ酸打よ びアラビノガラクタンに着目し, 様々な濃度および $\mathrm{pH}$

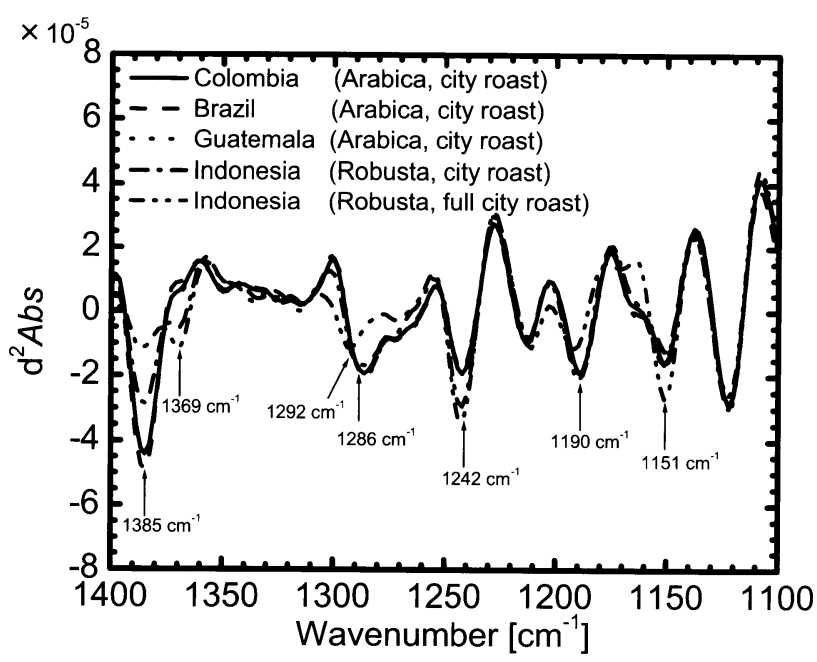

Fig. 19 Influences of varieties, geographical origins and roasting degree of coffee beans on IR spectral characteristics of brewed coffee.
の各水溶液の赤外分光スペクトルを測定した。その結 果, コーヒ一抽出液の主要 6 成分は，濃度と赤外分光 スペクトルの吸光度の二次微分值との間に高い相関が 認められた [46]. また, $\mathrm{pH}$ の変化による赤外分光スぺ クトルへの影響は, カフェイン, アラビノガラクタン は認められなかったが, 解離性成分であるクロロゲン 酸, クエン酸, キナ酸, およびトリゴネリンについては, その影響が認められた [46]. 解離性を有する 4 成分に ついては，赤外分光スペクトルの $\mathrm{pH}$ 依存性を解離平衡 の理論を用いて解析することにより各イオン種のスペ クトルの抽出を行い, 実際のコーヒ一抽出液スペクト ルと $\mathrm{pH}$ 依存性を考慮した主要 6 成分の合成スペクトル を比較した結果, 特徴的な波数において, 類似性が認 められた [46].

\section{2 「健康・食品アドバイザーロボット」の開発}

より人間に近づこうとするロボットの研究開発の中 では，人間の五感をセンサに置き換える試みが積極的 に行われているが，「嗅覚」と「味覚」については，そ の研究開発が遅れているとされてきた。そこで，独立 行政法人 新エネルギ・産業技術総合開発機構 (NEDO) の委託を受けて, NEC システムテクノロジー株式会社 と三重大学が共同で, 赤外線センサを用いた味見ので きるロボット「健康・食品アドバイザーロボット」を 開発した。 これは, 人間の舌の役割をする「赤外線セ ンサ」を NECのパートナーロボットPaPeRo[47]に装 着し，食品や飲物をこのセンサで測定することにより， 含まれている成分の種類や量を推定し，味見や食品に ついてのアドバイスなどを可能にした $[48,49]$. Fig. 20 に示すように, PaPeRoの大きさに合わせた腕を製作し 人間の舌の役割をする赤外線センサを一体化するよう に装着し，赤外線センサに食品や飲物をかざして赤外 線を照射して食品の脂肪分や糖分を測定できる [48]. また，それらの成分の有無や含有量による食品名の推 定（ワインの銘柄識別 [50] やチーズの種類判定 [48]）, および推定した食品情報や含有成分と健康に関する情 報の提供が行なうことが可能となる [49]. さらに，時 間経過や温度変化に伴う測定では，スペクトルに変化 が生じることがあり，このような現象を解析すること により，例えば，劣化食品や食べ頃を検出することが できるセンサ開発，添加物検知やトレーサビリティな どへの展開が期待される.

\section{8. おわりに}

上述のように，赤外線乾燥および赤外線照射による 殺菌効果に及ぼす試料の赤外分光特性の重要性は実験 的に示され，赤外域における拡散分光情報が赤外線乾 燥機構の解析に有効と考えられる。そこで, 主要な食 


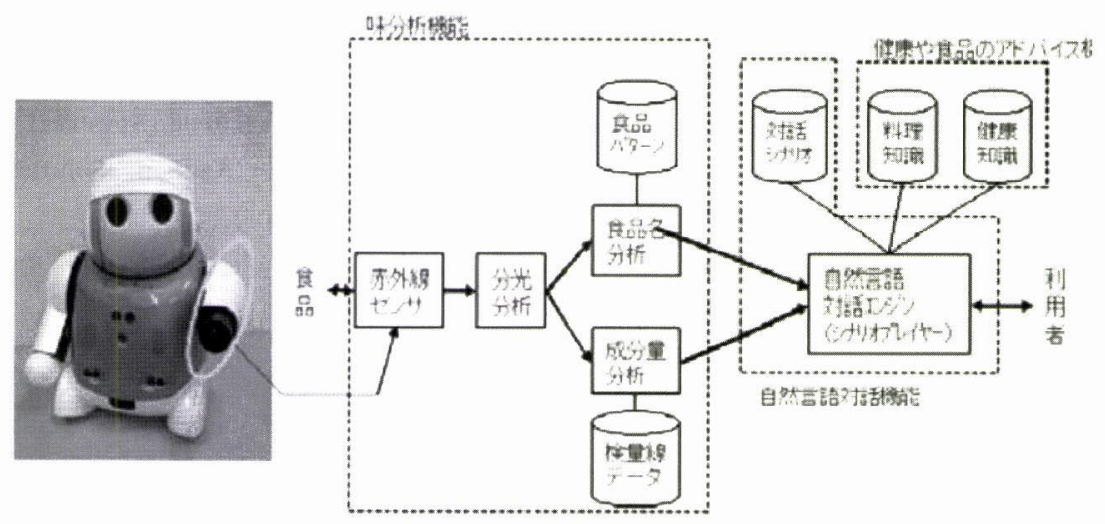

Fig. 20 Appearance and analytical structure of the tasting robot.

品成分の解析に加え, 構造を有する食品そのものの赤 外分光スペクトルの直接取得も期待される。一方, FT-IR と非常に多彩なアクセサリの登場で，さまざま な赤外分光スペクトルが取得できるようになっており， 光音響法，顕微 ATR 法, ファイバ ATR 法, ラマン分 光法，偏光子を用いたスペクトルなど鲖味深い話題は 非常に多い。そのなかで，本稿では，ATR 法による糖 類の赤外分光を起点として, 食品加工などの分野への 赤外分光法の様々な応用例を示した。食品の主要成分 のひとつであるタンパク質などに関する振動分光研究 は古くから行われ，近赤外分光，ラマン分光 [51] 含 めて新たな展開をみせている。さらに，光波と電波の 境界（束縛並進レベルでの分子振動に基づく遠赤外と ミリ波の間）にあり，技術的に立ち後れていたテラへ ルツ帯 $(300 \mathrm{GHz} \sim 10 \mathrm{THz}$ ，波長に換算すると 30 一 $1000 \mu \mathrm{m})$ では，近年ブレークスルーとなりそうな装置 が開発されたこともあり，この周波数帯の電磁波の特 徵をいかした分光，イメージング，各種検査，そして 食品, バイオ, 医学への応用など $\mathrm{THz}$ 領域の研究が活 発になってきている[52].

謝辞 本稿で述べた研究は, 大学院生時代から現在 に至るまで続けている研究テーマである。東京農工 大学名誉教授・清水賢先生, 三重大学副学長 ·龟岡 孝治先生をはじめ多くの先生方からは研究の方向性 から解析方法に至るまでご教示いただき，また多く の先輩・後輩諸氏や優秀な院生・卒論生などととも に本研究に関わる機会を得，本賞を受賞する栄誉に 浴したことを深く感謝いたします.

\section{引用 文 献}

[1] N. J. Harrick; "Internal Reflection Spectroscopy", Harrick Scientific Corporation. 1967.

[2] F. M. Mirabella, N. J. Harrick; "Internal Reflection
Spectroscopy: Review and Supplement”, Harrick Scientific Corporation. 1985.

[3] 橋本篤，高橋誠，本多太次郎，清水賢，渡䢌敦夫，柴田行 男; サッマイモの充填層加熱におけるマルトースの生成 量と伝熱機構. 化学工学論文集，17，634-638 (1991).

[4] J. Sawai, T. Nakai, A. Hashimoto, M. Shimizu; A Comparison of the Hydrolysis of Sweet Potato Starch with $\beta$-Amylase and Infrared Radiation Allows Prediction of Reducing Sugar Production. Int. J. Food Sci. Technol., 39, 967-974 (2004).

[5] 橋本篤，高橋誠，本多太次郎，清水賢，渡辺敦夫; サッマ イモ内に打ける赤外線エネルギの浸透性. 日本食品工業 学会誌, 37, 887-893 (1990).

[6] A. Hashimoto, T. Kameoka; Penetration of Infrared Radiation within a Vegetable Model. Food Sci. Technol. Int. Tokyo, 3, 373-378 (1997).

[7] 日本工業標準調相会 ; 遠赤外線用語, JIS Z 8117 (2002).

[8] A. Hashimoto, K. Hirota, T. Honda, M. Shimizu, A. Watanabe; Factors Influencing Constant Drying Rate of Wet Granular Bed Irradiated by Infrared Radiation. J. Chem. Eng. Japan, 24, 748-755 (1991).

[9] A. Hashimoto, Y. Yamazaki, M. Shimizu, S. Oshita; Drying Characteristics of Gelatinous Materials Irradiated by Infrared Radiation. Drying Technol., 12, 1029-1052 (1994).

[10] A. Hashimoto, T. Kameoka, M. Nitta: Infrared Drying Characteristics of Wet Porous Materials, Food Sci. Technol. Int. Tokyo, 3, 294-299 (1997).

[11] A. Hashimoto, T. Kameoka; Effect of Infrared Irradiation on Drying Characteristics of Wet Porous Materials. Drying Technol., 17, 1613-1626 (1999).

[12] A. Hashimoto, S. Stenström, T. Kameoka; Simulation of Convective Drying of Wet Porous Materials. Drying Technol., 21, 1411-1431 (2003).

[13] A. Hashimoto, T. Kameoka; Prediction of Water Sorption in Vegetables by a Modified Dubinin-Astakhov Equation. 
Food Sci. Technol. Int. Tokyo, 4, 227-229 (1998).

[14] A. Hashimoto, K. Nakanishi, T. Kameoka; Water Sorption Analysis on Vegetables Using Modified DubininAstakhov Parameters. Drying Technol., 22, 225-236 (2004).

[15] 橋本篤, 清水賢, 五十嵐英夫; 生理的リン酸緩衝液中に浮 遊する細菌の殺菌に及ぼす遠赤外線の影響。化工論文集, 17, 627-633 (1991).

[16] A. Hashimoto, H. Igarashi, M. Shimizu; Far-Infrared Irradiation Effect on Pasteurization of Bacteria on or within Wet-Solid Medium. J. Chem. Eng. Japan, 25, 666-671 (1992).

[17] A. Hashimoto, J. Sawai, H. Igarashi, M. Shimizu; Effect of Far-Infrared Irradiation on Pasteurization of Bacteria Suspended in Liquid Medium below Lethal Temperature. J. Chem. Eng. Japan, 25, 275-281 (1992).

[18] A. Hashimoto, J. Sawai, H. Igarashi, M. Shimizu; Irradiation Power Effect on IR Pasteurization below Lethal Temperature of Bacteria. J. Chem. Eng. Japan, 26, 331-333 (1993).

[19] J. Sawai, K. Sagara, H. Igarashi, A. Hashimoto, T. Kokugan, M. Shimizu; Injury in Escherichia coli in Physiological Phosphate-Buffered Saline Induced by Far-Infrared Irradiation. J. Chem. Eng. Japan, 28, 294-299 (1995).

[20] J.Sawai, K. Sagara, S. Kasai, H. Igarashi, A. Hashimoto, T. Kokugan, M. Shimizu, H. Kojima; Far-Infrared Irradiation-induced Injuries to Escherichia coli at Below the Lethal Temperature. J. Ind. Microbiol. Biotechnol., 24, 19-24 (2000).

[21] J. Sawai, K. Sagara, A. Hashimoto, M. Shimizu; Inactivation of Enzymes and Bacteria by Far-Infrared Radiative Heating. Int. J. Food Sci. Technol., 38, 661-667 (2003).

[22] J. Sawai, M. Fujisawa, T. Kokugan, M. Shimizu, H. Igarashi, A. Hashimoto, H. Kojima; Pasteurization of Bacterial Spores in Liquid Medium by Far-Infrared Irradiation. J. Chem. Eng. Japan, 30, 170-172 (1997).

[23] J. Sawai, K. Sagara, M. Miyagawa, T. Kokugan, M. Shimizu, H. Igarashi, A. Hashimoto,.H. Kojima; Injuries in Exponential Phase Cells of Escherichia coli Suspended in Physiological Phosphate Buffered Saline by Far-Infrared Irradiation. J. Chem. Eng. Japan, 30, 669-676 (1997).

[24] 亀岡孝治, 奥田知晴, 橋本篤, 野呂明美, 椎木靖彦, 伊藤 健介；FT-IR/ATR 法を用いた糖水溶液の赤外分光分析. 日本食品科学工学会誌，45，192-198 (1998).

[25] 狩野幹人, 中西健一, 橋本篤, 亀岡孝治; 溶媒効果を考虑 した二糖類の赤外分光解析. 日本食品科学工学会誌, $\mathbf{5 0}$, 57-62 (2003).
[26] M. Kanou, K. Nakanishi, A. Hashimoto, T. Kameoka; Influences of Monosaccharides and Its Glycosidic Linkage on Infrared Spectral Characteristics of Disaccharides in Aqueous Solutions. Appl. Spectrosc., 59, 885-892 (2005).

[27] 狩野幹人, 橋本篤, 椎木靖彦, 伊藤健介, 元永佳孝, 亀岡 孝治;FT-IR/ATR 法によるマルトオリゴ糖の重合度推定． 日本食品科学工学会誌，48，401-408（2001）.

[28] M. Kanou, A. Yamanaka, A. Hashimoto, T. Kameoka; Infrared Spectroscopic Analysis of Saccharides in Aqueous Solutions with Alkaline Metal Salts. Proceedings of 10th Asian Pacific Confederation of Chemical Engineering Conference (CD-ROM version), 3P-01-056 (2004).

[29] 亀岡孝治, 奥田知晴, 橋本篤, 野呂明美, 椎木靖彦, 伊藤 健介；食品糖成分分析への FT-IR/ATR 法の応用.日本食 品科学工学会誌, 45, 199-204 (1998).

[30] ウィンウィンミ1, 元永佳孝, 橋本篤, 亀岡孝治; 貯 蔵トマトの呼吸特性（第 1 報）一実験用貯蔵装置の試作 と大気圧下での貯蔵特性一 . 農業機械学会誌， 63，73-80 (2001).

[31] A. Hashimoto, S. Takada, Y. Motonaga, K. Nakanishi, T. Kameoka; Spectroscopic Determination of Acid and Sugar Content in Fruit Juice. In "Control Applications in Post-Harvest and Processing Technology 2001", Elsevier Science Ltd., Oxford, 2002, pp.209-214.

[32] J. C. Alberti, J. A. Phillips, D. J. Fink, F. M. Wacasz; OffLine Monitoring of Fermentation Samples by FTIR/ATR: A Feasibility Study for Real-Time Process Control. Biotechnol. Bioeng. Symp., 15, 689-722 (1985).

[33] P. Fayolle, D. Picque, B. Perret, E. Latrille, G. Corrieu; Determination of Major Compounds Alcoholic Fermentation by Middle-Infrared Spectroscopy: Study of Temperature Effects and Calibration Method. Appl. Spectrosc., 1325-1330 (1996).

[34] A. Hashimoto, T. Kameoka, Y. Shiinoki, K. Ito; Mid-Infrared Spectroscopic Determination of Sugar Contents in Culture Media. In "Computer Applications in Biotechnology 1998”, Elsevier Science Ltd., Oxford, 1998, pp.411-416.

[35] A. Hashimoto, T. Kameoka; Mid-Infrared Spectroscopic Determination of Sugar Contents in Plant-Cell Culture Media Using an ATR Method. Appl. Spectrosc., 54, 1005-1011 (2000).

[36] A. Hashimoto, A. Yamanaka, M. Kanou, K. Nakanishi, T. Kameoka; Simple and Rapid Determination of Metabolite Content in Plant Cell Culture Medium Using an FT-IR/ ATR Method. Bioprocess Biosyst. Eng., 27, 115-123 (2005). 
[37] A. Hashimoto, K. Nakanishi, Y. Motonaga, T. Kameoka; Sugar Metabolic Analysis of Suspensions of Plant Cells Using an FT-IR/ATR Method. Biotechnol. Prog., 17, 560-564 (2001).

[38] A. Hashimoto, A. Yamanaka, M. Kanou, F. Nahar, T. Kameoka; Effects of Pre-Cultivation on Sugar Metabolic Kinetics of Suspension Plant Cells Measured by MidInfrared Spectroscopy. J. Food Agric. Environ., 1, 168-175 (2003).

[39] A. Yamanaka, A. Hashimoto, M. Kanou, T. Kameoka; MIR Spectroscopic Analysis on Sugar Metabolic and Ethanol Productive Kinetics of Suspension TBY-2 and Rice Cells Pre-Cultured in Various Media. Bioprocess Biosyst. Eng., 27, 125-133 (2005).

[40] K. Nakanishi, A. Hashimoto, M. Kanou, T. Pan, T. Kameoka; Mid-Infrared Spectroscopic Measurement of Ionic Dissociative Materials in Metabolic Pathway. Appl. Spectrosc., 57, 1510-1516 (2003).

[41] A. Hashimoto, K. Asada, T. Matsuo, C. Teraura, T. Yamamura, K. Yasui, A. Yamanaka, M. Kanou, T. Kameoka; Mid-Infrared Spectroscopic Characteristics of Glycine in Aqueous Solution. Proceedings of 7th Asia-Pacific Conference of Biochemical Engineering (CD-ROM version), CUR-06 (2005).

[42] T. Pan, A. Hashimoto, M. Kanou, K. Nakanishi, T. Kameoka; Development of a Quantification System of Ionic Dissociative Materials in the Glycolytic Pathway Using an FT-IR/ATR Method. Bioprocess Biosyst. Eng., 26, 133-139 (2003).

[43] T. Pan, A. Hashimoto, M. Kanou, K. Nakanishi, T. Kameoka; Mid-Infrared Spectroscopic Quantification of Ionic Dissociative Metabolites Based on Three Spectral Extraction Methods. Japan J. Food Eng., 5, 23-31 (2004).

[44] A. Hashimoto, T. Pan, M. Kanou, K. Nakanishi, T. Kameoka; Mid-Infrared Spectroscopic Monitoring of Enzyme Reaction Associating with Ionic Dissociative Metabolites. In "Computer Applications in Biotechnology 2004”, Elsevier Science Ltd., Oxford, 2005, pp.375-380.

[45] A. Hashimoto, H. Mori, M. Kanou, A. Yamanaka, T. Kameoka; Mid-Infrared Spectroscopic Analysis on Brewed Coffee Characteristics. Proceedings of 10th Asian Pacific Confederation of Chemical Engineering Conference (CD-ROM version), 3P-01-068 (2004).
[46] 森久典, 橋本篤, 東原誠, 木村良太郎, 龟岡孝治; コーヒー 抽出液主要成分の赤外分光解析. 日本食品科学工学会第 50 回大会講演要旨集（2003）。

[47] Y. Fujita; Personal Robot PaPeRo. J. Robotics Mechatronics, 14, 60-63 (2002)

[48] H. Shimazu, K. Kobayashi, A. Hashimoto, T. Kameoka; Tasting Robot: a Personal Robot with an Optical-Tongue. Proceedings of ISR2005 (2005).

[49] 島津秀雄，橋本篤；味見ができるロボットの開発．「超 五感センサの開発最前線」，エヌ・ティー・エス，東京， pp.465-474 (2005)

[50] A. Hashimoto, M. Kanou, A. Yamanaka, T. Kameoka, K. Kobayashi, H Shimazu; Mid-Infrared Spectroscopic Analysis for Characterizing Wines. Abstracts of 3rd International Conference of Vibrational Spectroscopy, P11.14 (2005)

[51] 海野雅司，山内清語；ラマン分光法と量子化学計算によ る光受容タンパク質の動的構造の解析. 生物物理, 43 , $58-63(2003)$

[52] 川瀬晃道，伊藤弘昌；テラフォトニクス光源－波長可変 $\mathrm{THz}$ 波の発生と応用可能性一 . 応用物理, 71，167-172 (2002).

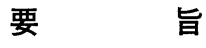

食品加工プロセスに打ける赤外線利用に関して，放 射伝熱学と分光学的な側面から総合的に論述した。赤 外線の熱的操作への応用として, 食品モデルの乾燥と 殺菌に関する研究を行った。食品モデルの赤外線乾燥 特性に及ぼす因子に着目し，赤外線乾燥の定量的評価 には試料の赤外域における拡散分光情報の理解が重要 であることが示された。 また，細菌の赤外線殺菌は従 来法加熱殺菌よりも効果的であり，その効果は試料表 面近傍における赤外線エネルギの吸収とバルク温度に 起因することが示唆された。そこで，赤外分光法によ る食品の定性・定量解析に関する研究を行った。 それ らの成果に応用することにより，懸濁細胞の動的糖代 謝挙動の把握，イオン解離性代謝物質が関与する酵素 反応過程のモニタリング，および食味ロボットの開発 が可能となった。 以上より，これらの研究成果は，食 品加工プロセスにおける赤外線利用に関する重要な指 針となりうるものである 